\title{
NODAL wt Allele
}

National Cancer Institute

\section{Source}

National Cancer Institute. NODAL wt Allele. NCI Thesaurus. Code C96044.

Human NODAL wild-type allele is located in the vicinity of 10q22.1 and is approximately

$10 \mathrm{~kb}$ in length. This allele, which encodes nodal homolog protein, plays a role in the

modulation of embryonic mesoderm and axis formation. Mutation of the gene is associated with visceral heterotaxy autosomal type 5 . 